\title{
Regional variations in wheezing illness in British children: effect of migration during early childhood
}

\author{
D P Strachan, J Golding, H R Anderson
}

Department of Epidemiology and Population Sciences, London School of Hygiene and Tropical Medicine, Keppel Street, London WC1E 7HT D P Strachan Department of Child Health, Royal Hospital for Sick Children, Bristol BS2 8BJ

J Golding

Department of Public Health Sciences, St George's Hospital Medical School, London SW17 ORE H R Anderson

Correspondence to: Dr Strachan, at Departmen of Public Health Sciences, St George's Hospital Medical School, London SW17 ORE

Accepted for publication January 1990

\begin{abstract}
Study objective-The aim was to examine the regional distribution of wheezing illness among British children, and the age at which geographical differences may be determined.
\end{abstract}

Design-Cross sectional analyses and study of interregional migrants were used.

Subjects-The subjects were national cohorts of British children born in 1958 and 1970.

Measurements and main results-The regional distribution of wheezing illness showed significant heterogeneity at age 5 (1970 cohort) and 7 (1958 cohort). In both cohorts, children in Scotland had a low prevalence of wheeze, which could not be attributed to underreporting of mild cases. There was a less consistent tendency for high prevalence in Wales, and in the South Western and Midlands regions of England. In the 1958 cohort, the regional differentials diminished progressively with age and were negligible at age 23 . There was a poor correlation between the regional distribution of childhood asthma and the common geographical pattern shown by eczema in infancy and hay fever at age 23. Analysis of interregional migrants suggested that the regional variation in each cohort at age 5-7 was primarily related to the region of current residence, and not to the region of birth.

Conclusions-Genetic constitution, perinatal exposures, or early childhood experiences are unlikely to account for the regional variation in wheezing illness. Although local patterns of symptom reporting or disease labelling may be acquired by parents who move to a new region, environmental factors operating at a regional level probably determine the prevalence of asthma in primary school children. These influences do not appear to have long lasting effects upon the tendency to wheeze in adolescence and early adulthood.

Comparisons of child populations of similar genetic stock living in subsistence economies and in urban "Westernised" environments have demonstrated large differences in the prevalence of wheezing ${ }^{1}$ and exercise induced bronchospasm, ${ }^{2}$ which suggest that environmental factors are a major determinant of the high prevalence of childhood asthma found in many Western industrialised countries. ${ }^{3}$ Studies of international migrants have generated conflicting conclusions regarding the age at which these differences might be determined. Among Tokelauan children in New Zealand, no significant difference was found in the prevalence of asthma between those born into a traditional Pacific island lifestyle on Tokelau, and those born in New Zealand. ${ }^{1}$ On the other hand, in a study of schoolchildren in Birmingham, England, children of West Indian parents who had been born in Britain had a higher prevalence of asthma and wheeze than those born abroad. ${ }^{4}$ For the children of non-Kenyan Asian parents the prevalence of asthma was similar in first and second generation immigrants, but Asian children born in Kenya carried a high risk of asthma. ${ }^{4}$ Among adult asthmatics from the Indian subcontinent attending a London outpatient clinic, the age at onset of asthma was later than among native Britons, and often occurred after immigration, 5 suggesting that exposures acquired in Britain might be of aetiological importance.

Studies of the determinants of wheezing in two national cohorts of British children born in $1958^{6}$ and $1970^{7}$ found remarkably little variation with socioeconomic and family factors, but in both cohorts region of residence appeared as a significant predictor of wheeze. This paper compares the regional patterns in the two cohorts and analyses the effect of migration between regions in early life, with the aim of clarifying the critical age at which geographical differentials in childhood asthma within Britain may be determined.

\section{Methods}

The National Child Development Study (1958 cohort) has attempted to follow up children in England, Scotland and Wales who were born during one week in March $1958^{8}$ at ages $7,11,16$, and 23. ${ }^{9}$ The Child Health and Education Study $(1970 \text { cohort })^{7}$ is based upon a similar longitudinal study of British children born during one week in April 1970.10 Each study included questions about wheezing illness at each follow up, and areas of birth and current residence were recorded. For the purpose of this study, areas were aggregated to the regions in use at birth for the 1958 cohort, ${ }^{11}$ except that Greater London was distinguished (using the post-1965 boundary). This resulted in 12 regions of comparable size, with approximately 1000 children from each cohort in each region.

\section{QUESTIONNAIRE INFORMATION}

The parents of the 1958 cohort were asked the following questions relating to wheezing illness and atopic disease: 
At age 7: Has your child ever had attacks of asthma? If so, how many times in the past 12 months?

Has your child ever had attacks of bronchitis with wheezing? If so, how many times in the past 12 months?

Did your child have eczema in the first year of life?

At age 11: Has your child ever had attacks of asthma? If yes, what is the frequency of attacks?

Has your child ever had attacks of wheezy bronchitis? If yes, what is the frequency of attacks?

At age 16: Has your child ever had an attack of asthma or wheezy bronchitis? If yes, when did the most recent attack occur?

Asthma, bronchitis with wheezing, and wheezy bronchitis were treated as a single disease entity for the purpose of analysis. The reasons for this have been discussed elsewhere. ${ }^{6}$ The cohort members themselves were interviewed at 23 years of age and the following questions were asked:

Since your sixteenth birthday have you had an attack of asthma or wheezy bronchitis? if yes, have you had an attack in the last 12 months? In the last 12 months have you suffered from hay fever?

The parents of the 1970 cohort were asked the following question when their child was five years of age:

Has your child ever had one or more attacks or bouts in which he/she had wheezing on the chest, regardless of the cause? If yes, how many attacks occurred in the first 12 months, between his/her first and fourth birthdays and since his/her fourth birthday?

The parents of children who had wheezed were then asked to describe what they were told about the diagnosis in their own words.

\section{STATISTICAL ANALYSIS}

Statistical analysis of selected data from each cohort was performed using Statistical Analysis System (SAS). ${ }^{12}$ Multiple logistic regression models were fitted using Generalised Interactive Modelling System (GLIM). ${ }^{13}$

Comparisons of the regional distribution of cases in the two cohorts were made by $\chi^{2}$ tests comparing the observed number of cases in each region in each cohort with the number that would have been expected under the null hypothesis that the ratio of the prevalence in each region to the prevalence for Great Britain for each cohort was equal to the average of the prevalence ratios observed for that region in each cohort. Calculation of expected numbers of cases took into account the somewhat different regiona distribution of the population at risk in the two cohorts. A similar approach was used to compare the regional distribution of infant eczema and adult hay fever in the 1958 cohort.

In order to determine the independent effects of region of birth and region of current residence upon wheezing illness at age 5 (1970 cohort) or 7 (1958 cohort), the prevalence of the outcome among the non-migrants in each region was used as a quantitative index of the risk of wheezing associated with that region. In multiple logistic regression models, the prevalence log odds associated with region of birth and region of current residence were used as continuous explanatory variables. In order to test the possibility that children of mobile families might have a different underlying risk of reported wheezing illness (independent of their area of residence or birth), an additional dichotomous explanatory variable was included to distinguish between interregional migrants and nonmigrants.

\section{Results}

Information about asthma and wheezy bronchitis by age 7 years in the 1958 cohort was available for 14523 children, of whom 12856 had complete information relating to episodes in the past year and region of birth. The latter group comprised $77 \%$ of the 16606 survivors from the 1958 Perinatal Mortality Survey. ${ }^{14}$ Response rates at subsequent follow ups were lower, but it has been shown that non-response bias in respect of wheezing illness is minimal. ${ }^{6}$ In the 1970 cohort, information about wheezing in the first five years of life was available for 12914 children, of whom 11988 had complete disease and residence data. These comprised $75 \%$ of the 16004 survivors from the 1970 British Births Survey who had been born in England, Scotland or Wales. ${ }^{7}$

WHEEZING IN CHILDHOOD IN THE 1958 COHORT The regional distribution of asthma and/or wheezy bronchitis at age 7 years in the 1958 cohort is shown in table I. The cumulative prevalence by age 7 was lowest in Scotland, and highest in the Midland region of England. In general, regions with a high cumulative prevalence also had a high period prevalence in the past year at 7 . When the case definition was restricted to those children with one or more attacks of wheeze in the past year, Scotland remained the region with the lowest prevalence, but the Midland region was no longer associated with a particularly high risk. Tests of overall heterogeneity in the regional prevalence figures confirmed that the variations in cumulative prevalence $\left(\chi^{2}=60 \cdot 7, \mathrm{df}=11\right.$, $\mathrm{p}=<0.0001)$ and annual period prevalence $\left(\chi^{2}=35.4, \mathrm{df}=11, \mathrm{p}=0.0002\right)$ were unlikely to have occurred by chance. Even if Soctland was excluded, the variation among the remaining regions was significant for both cumulative prevalence $\left(\chi^{2}=26.4, \mathrm{df}=10, \mathrm{p}=0.003\right)$ and period prevalence $\left(\chi^{2}=25.0, \mathrm{df}=10, \mathrm{p}=0.005\right)$.

The proportion of prevalent cases with more than one attack in the previous year was investigated as a crude index of the severity of asthma. This did not vary more than would be expected by chance $\left(\chi^{2}=11.8, \mathrm{df}=11, \mathrm{p}=0.38\right)$, 
and showed little tendency to vary with the prevalence of wheeze. Overall, about one sixth of the wheezy children had been diagnosed with asthma. This proportion varied considerably from region to region, to an extent which was unlikely to be due to chance alone $\left(\chi^{2}=24.9\right.$, $\mathrm{df}=11, \mathrm{p}=0.01)$. There was no relationship between the proportion diagnosed with asthma and the prevalence or severity of wheeze in each region.

WHEEZING IN CHILDHOOD IN THE 1970 COHORT A similar analysis of the regional distribution of wheezing in the 1970 cohort at age 5 years is shown in table II. Again Scotland showed the lowest cumulative and period prevalence, and the lowest proportion of children with more than one attack in the past year. The highest prevalences were found in Wales and the South Western Region of England. The cumulative and annual period prevalence in the Midland region, although above average, was not exceptional. As in the 1958 cohort, regions with a high cumulative prevalence tended to have a high prevalence of wheezing in the past year. The overall heterogeneity was greater than could be expected by chance for both cumulative prevalence $\left(\chi^{2}=26.4, \mathrm{df}=11, \mathrm{p}=0.006\right)$ and annual period prevalence $\left(\chi^{2}=30.5, \quad \mathrm{df}=11, \quad \mathrm{p}=0.001\right)$. However, much of this variation was due to the low prevalence in Scotland. Excluding Scotland, the variation in cumulative prevalence was just significant $\left(\chi^{2}=18.4, \mathrm{df}=10, \mathrm{p}=0.049\right)$ but that for period prevalence was not $\left(\chi^{2}=11 \cdot 5, \mathrm{df}=10\right.$, $p=0.32$ ).

The proportion of prevalent cases with more than one attack in the previous year varied more than would be expected by chance $\left(\chi^{2}=20.9\right.$, $\mathrm{df}=11, \mathrm{p}=0.034)$. This index of severity tended to be high in the regions with high cumulative and period prevalence (Wales and South Western) and was low in Scotland. Overall, about one tenth
Table I Prevalence of asthma and/or wheezy bronchitis by region of residence at age 7 years in the 1958 birth cohort. Numbers of children in parentheses

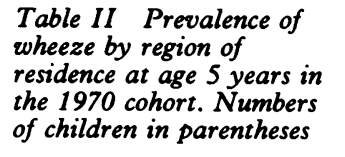

\begin{tabular}{|c|c|c|c|c|c|}
\hline \multirow[b]{2}{*}{ Region at 7 years } & \multicolumn{3}{|c|}{${ }^{\circ}$ W With asthma and/or wheezy bronchitis } & \multirow{2}{*}{$\begin{array}{l}o \text { o Prevalent } \\
\text { cases with } \\
>1 \text { attack }\end{array}$} & \multirow{2}{*}{$\begin{array}{l}\text { o Cumulative } \\
\text { cases diagnosed } \\
\text { as asthma }\end{array}$} \\
\hline & $\begin{array}{l}\text { At any age } \\
\text { by } 7\end{array}$ & $\begin{array}{l}\text { In past year } \\
\text { at } 7\end{array}$ & $\begin{array}{l}>1 \text { attack } \\
\text { in past year }\end{array}$ & & \\
\hline Scotland & $\begin{array}{c}13 \cdot 0 \\
(207 / 1588)\end{array}$ & $\begin{array}{c}6.9 \\
(102 / 1487)\end{array}$ & $\begin{array}{c}3.9 \\
(58 / 1487)\end{array}$ & $\begin{array}{c}57 \\
(58 / 102)\end{array}$ & $\begin{array}{c}17 \\
(35 / 207)\end{array}$ \\
\hline Northern & $\begin{array}{c}18 \cdot 2 \\
(197 / 1081)\end{array}$ & $\begin{array}{c}10 \cdot 7 \\
(107 / 996)\end{array}$ & $\begin{array}{c}5.9 \\
(59 / 996)\end{array}$ & $\begin{array}{c}55 \\
(59 / 107)\end{array}$ & 13 \\
\hline North Western & 19.1 & $\begin{array}{l}9.8 \\
9\end{array}$ & 5.9 & 60 & 17 \\
\hline E \& W Ridings & $\begin{array}{c}(360 / 1882) \\
16 \cdot 1\end{array}$ & $\begin{array}{c}(167 / 1701) \\
7.0\end{array}$ & $\begin{array}{c}(101 / 1701) \\
3.4\end{array}$ & $\begin{array}{c}(101 / 167) \\
49\end{array}$ & $\begin{array}{l}(62 / 360) \\
10\end{array}$ \\
\hline Narth Midlande & $(194 / 1207)$ & $(76 / 1091)$ & $(37 / 1091)$ & $(37 / 76)$ & $(19 / 194)$ \\
\hline North Midlands & $\begin{array}{c}20 \cdot 2 \\
(217 / 1075)\end{array}$ & $\begin{array}{c}8 \cdot 3 \\
(78 / 940)\end{array}$ & $\begin{array}{c}4 \cdot 4 \\
(41 / 940)\end{array}$ & $\begin{array}{c}53 \\
(41 / 78\end{array}$ & 15 \\
\hline Eastern & 16.8 & 8.5 & 4.7 & $\begin{array}{c}(41 / 18) \\
55\end{array}$ & $\begin{array}{c}(32 / 211) \\
18\end{array}$ \\
\hline Greater London & $\begin{array}{c}(201 / 1194) \\
19 \cdot 3\end{array}$ & $\begin{array}{c}(92 / 1089) \\
8.6\end{array}$ & $\begin{array}{c}(51 / 1089) \\
4 \cdot 7\end{array}$ & $\begin{array}{l}(51 / 92) \\
55\end{array}$ & $(37 / 201)$ \\
\hline & $(318 / 1646)$ & $(125 / 1459)$ & $(69 / 1459)$ & $(69 / 125)$ & $(61 / 318)$ \\
\hline South Eastern & $\begin{array}{c}19.0 \\
(167 / 878)\end{array}$ & $\begin{array}{c}9 \cdot 7 \\
(77 / 791)\end{array}$ & $\begin{array}{c}5.4 \\
(43 / 791)\end{array}$ & $\begin{array}{c}56 \\
(43 / 77)\end{array}$ & $\begin{array}{l}17 \\
(29 / 167)\end{array}$ \\
\hline Southern & 17.1 & 8.5 & 5.5 & 64 & 24 \\
\hline South Western & $\begin{array}{c}(154 / 903) \\
19.8\end{array}$ & $\begin{array}{c}(70 / 821) \\
9 \cdot 3\end{array}$ & $\begin{array}{c}(45 / 821) \\
5.0\end{array}$ & $\begin{array}{c}(45 / 70) \\
53\end{array}$ & $\begin{array}{c}(37 / 154) \\
16\end{array}$ \\
\hline Midlands & $\begin{array}{c}(174 / 881) \\
22 \cdot 4\end{array}$ & $\begin{array}{c}(73 / 783) \\
12.0\end{array}$ & $\begin{array}{c}(39 / 783) \\
5.5\end{array}$ & $\begin{array}{l}(39 / 73) \\
45\end{array}$ & $(28 / 174)$ \\
\hline & $(320 / 1428)$ & $(152 / 1264)$ & $(69 / 1264)$ & $(69 / 152)$ & $(43 / 320)$ \\
\hline Wales & $\begin{array}{c}20.5 \\
(156 / 760)\end{array}$ & $\begin{array}{c}9 \cdot 6 \\
(65 / 675)\end{array}$ & $\begin{array}{c}5.3 \\
(36 / 675)\end{array}$ & $\begin{array}{c}55 \\
(36 / 65)\end{array}$ & $\begin{array}{c}24 \\
(37 / 156)\end{array}$ \\
\hline Total & $\begin{array}{c}18 \cdot 4 \\
(2665 / 14523)\end{array}$ & $\begin{array}{c}9.0 \\
\text { (1184/13 097) }\end{array}$ & $\begin{array}{c}4.9 \\
(648 / 13097)\end{array}$ & $\begin{array}{c}55 \\
(648 / 1184)\end{array}$ & $\begin{array}{c}17 \\
(446 / 2665)\end{array}$ \\
\hline
\end{tabular}

\begin{tabular}{|c|c|c|c|c|c|}
\hline \multirow[b]{2}{*}{ Region at 5 years } & \multicolumn{3}{|c|}{$o_{o}$ With wheezing } & \multirow{2}{*}{$\begin{array}{l}o_{o} \text { Prevalent } \\
\text { cases with } \\
>1 \text { attack }\end{array}$} & \multirow{2}{*}{$\begin{array}{c}{ }_{0}^{\circ} \text { Cumulative } \\
\text { cases diagnosed } \\
\text { as asthma }\end{array}$} \\
\hline & $\begin{array}{l}\text { At any age } \\
\text { by } 5\end{array}$ & $\begin{array}{l}\text { In past year } \\
\text { at } 5\end{array}$ & $\begin{array}{l}>1 \text { attack } \\
\text { in past year }\end{array}$ & & \\
\hline Scotland & \multirow{17}{*}{$\begin{array}{c}17 \cdot 6 \\
(202 / 1149) \\
22 \cdot 1 \\
(210 / 950) \\
19 \cdot 0 \\
(327 / 1723) \\
20 \cdot 6 \\
(209 / 1017) \\
19 \cdot 1 \\
(182 / 951) \\
19 \cdot 6 \\
(228 / 1163) \\
21 \cdot 3 \\
(276 / 1296) \\
21 \cdot 1 \\
(179 / 850) \\
22 \cdot 5 \\
(219 / 974) \\
23 \cdot 5 \\
(165 / 703) \\
21.7 \\
(304 / 1402) \\
24 \cdot 6 \\
(181 / 736)\end{array}$} & \multirow{17}{*}{$\begin{array}{c}6 \cdot 2 \\
(69 / 1113) \\
10 \cdot 8 \\
(98 / 910) \\
8 \cdot 8 \\
(144 / 1643) \\
10 \cdot 4 \\
(101 / 971) \\
9 \cdot 5 \\
(87 / 919) \\
9 \cdot 6 \\
(108 / 1123) \\
9 \cdot 6 \\
(118 / 1229) \\
10 \cdot 6 \\
(86 / 815) \\
11 \cdot 3 \\
(104 / 924) \\
12 \cdot 4 \\
(83 / 667) \\
10 \cdot 8 \\
(144 / 1340) \\
11 \cdot 2 \\
(78 / 697)\end{array}$} & \multirow{17}{*}{$\begin{array}{c}2 \cdot 5 \\
(28 / 1113) \\
4 \cdot 4 \\
(40 / 910) \\
4 \cdot 1 \\
(68 / 1643) \\
4 \cdot 9 \\
(48 / 971) \\
4 \cdot 6 \\
(42 / 919) \\
5 \cdot 6 \\
(63 / 1123) \\
4 \cdot 8 \\
(59 / 1229) \\
4 \cdot 3 \\
(35 / 815) \\
4 \cdot 8 \\
(44 / 924) \\
7 \cdot 2 \\
(48 / 667) \\
4 \cdot 6 \\
(62 / 1340) \\
6 \cdot 7 \\
(47 / 697)\end{array}$} & \multirow{17}{*}{$\begin{array}{c}41 \\
(28 / 69) \\
41 \\
(40 / 98) \\
47 \\
(68 / 144) \\
48 \\
(48 / 101) \\
48 \\
(42 / 87) \\
58 \\
(63 / 108) \\
50 \\
(59 / 118) \\
41 \\
(35 / 85) \\
42 \\
(44 / 104) \\
58 \\
(48 / 83) \\
43 \\
(62 / 144) \\
60 \\
(47 / 78)\end{array}$} & \multirow{17}{*}{$\begin{array}{c}9 \\
(18 / 200) \\
6 \\
(13 / 210) \\
12 \\
(38 / 323) \\
9 \\
(19 / 208) \\
9 \\
(16 / 178) \\
15 \\
(33 / 226) \\
12 \\
(32 / 274) \\
7 \\
(13 / 178) \\
10 \\
(21 / 217) \\
16 \\
(27 / 165) \\
8 \\
(23 / 297) \\
9 \\
(16 / 181)\end{array}$} \\
\hline Northern & & & & & \\
\hline & & & & & \\
\hline North Western & & & & & \\
\hline F \& W Ridinos & & & & & \\
\hline E \& W Ridings & & & & & \\
\hline North Midlands & & & & & \\
\hline Fostern & & & & & \\
\hline Eastern & & & & & \\
\hline Greater London & & & & & \\
\hline South Fostern & & & & & \\
\hline South Eastern & & & & & \\
\hline Southern & & & & & \\
\hline South Western & & & & & \\
\hline & & & & & \\
\hline Midlands & & & & & \\
\hline Wales & & & & & \\
\hline Total & $\begin{array}{c}20 \cdot 8 \\
(2682 / 12914)\end{array}$ & $\begin{array}{c}9.9 \\
(1220 / 12351)\end{array}$ & $\begin{array}{c}4 \cdot 7 \\
(584 / 12351)\end{array}$ & $\begin{array}{c}48 \\
(584 / 1220)\end{array}$ & $\begin{array}{c}10 \\
(269 / 2657)\end{array}$ \\
\hline
\end{tabular}


of the wheezy children had received a diagnosis of asthma, but as in the 1958 cohort there was substantial heterogeneity across regions $\left(\chi^{2}=21 \cdot 8, \mathrm{df}=11, \mathrm{p}=0.026\right)$. Again, there was no relationship between the proportion diagnosed with asthma and the prevalence or severity of wheeze in each region.

COMPARISON OF THE TWO COHORTS

The low prevalence in Scotland in each cohort was clearly consistent but the remaining prevalence figures showed a poor correlation. Since each prevalence was based on rather small numbers, $\chi^{2}$ tests, as described in the methods section, were used to determine whether the disparity could reasonably be attributed purely to sampling variation. For cumulative prevalence by age 7 (1958 cohort) or 5 (1970 cohort), the distribution of cases by region differed rather more than might be expected by chance $\left(\chi^{2}=17.9\right.$, $\mathrm{df}=11, \mathrm{p}=0.084)$. For annual period prevalence, a chance explanation was more likely, although even here an underlying difference in the regional pattern was quite probable $\left(\chi^{2}=15 \cdot 7, \mathrm{df}=11\right.$, $\mathrm{p}=0 \cdot 15$ ).

WHEEZING IN ADOLESCENCE AND EARLY ADULTHOOD The prevalence of asthma and/or wheezy bronchitis in the past year at ages 11,16 , and 23 was compared to the regional distribution of wheezing illness at age 7 in the 1958 cohort (table III). The regional variation had largely diminished by age 11 , and the low prevalence in Scotland was no longer so apparent. Tests of heterogeneity for the prevalences at age 11,16 and 23 were all non-significant $\left(\chi^{2}=14.9,10.3\right.$ and 13.5 respectively, $\mathrm{df}=11$ ).

\section{OTHER ATOPIC DISEASES}

Reports of eczema in the first year of life and hay fever at age 23 in the 1958 cohort are presented by region of residence at age 7 years in table IV. The patterns of these two manifestations of atopy were

Table III Prevalence of asthma and/or wheezy bronchitis at different ages by region of residence at age 7 years in the 1958 cohort. Numbers of children in parentheses

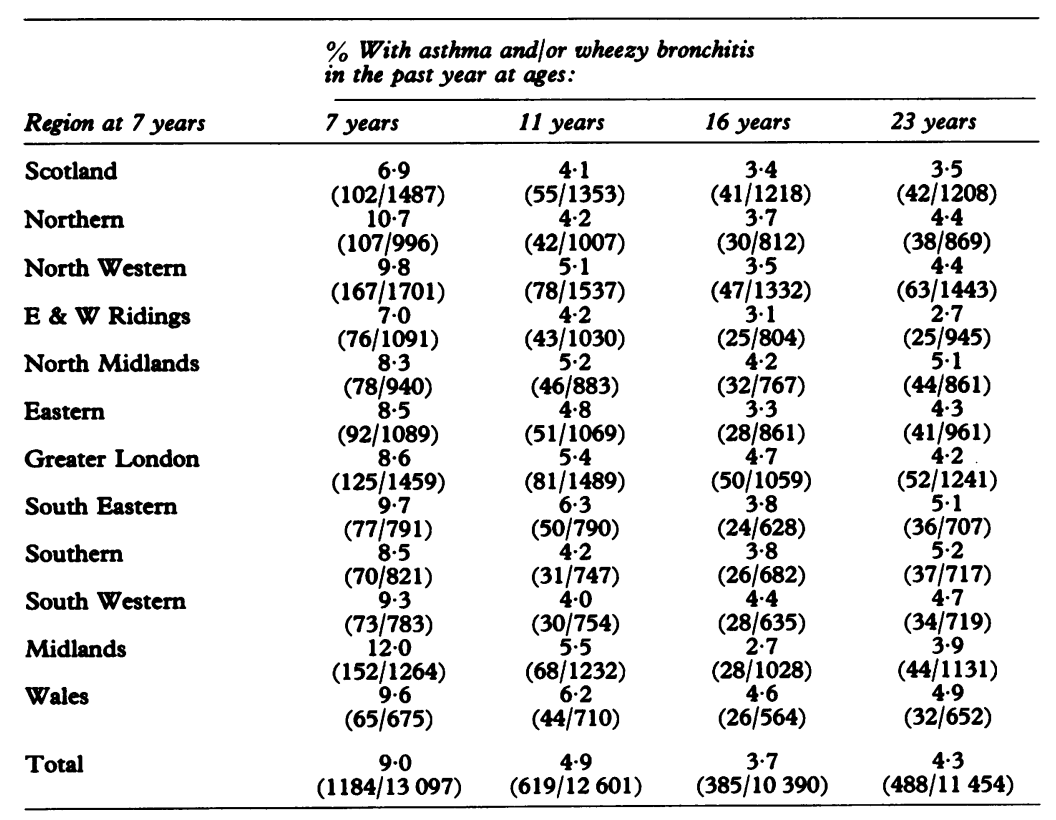

Table IV Prevalence of infant eczema and adult hayfever by region of residence at age seven years in the 1958 cohort. Numbers of children in parentheses

\begin{tabular}{|c|c|c|}
\hline Region at 7 years & $\begin{array}{l}\% \text { With eczema } \\
\text { in first year } \\
\text { of life }\end{array}$ & $\begin{array}{l}\text { \% With hay fever } \\
\text { in past year } \\
\text { at age } 23\end{array}$ \\
\hline Scotland & $\begin{array}{c}3.8 \\
(60 / 1582)\end{array}$ & $\begin{array}{c}14 \cdot 1 \\
(69 / 106\end{array}$ \\
\hline Northern & $\begin{array}{c}(00 / 1302) \\
3.5\end{array}$ & $\begin{array}{c}10.9 \\
100\end{array}$ \\
\hline North Western & $\begin{array}{l}8 / 1076) \\
3.6\end{array}$ & $\begin{array}{c}(94 / 865) \\
14.8\end{array}$ \\
\hline E \& W Ridings & $\begin{array}{c}68 / 1882) \\
5 \cdot 5\end{array}$ & $\begin{array}{c}(213 / 1438) \\
13.9\end{array}$ \\
\hline & $(67 / 1209)$ & (131/943) \\
\hline North Midlands & $5 \cdot 6$ & 17.3 \\
\hline Eastern & $6 \cdot 1$ & $\begin{array}{l}19 \cdot 4 \\
\end{array}$ \\
\hline Greater London & $(73 / 1192)$ & $(185 / 956)$ \\
\hline & $(96 / 1646)$ & $\begin{array}{c}21.3 \\
(263 / 1233)\end{array}$ \\
\hline South Eastern & 5.8 & 19.7 \\
\hline Southern & $\begin{array}{c}(31 / 814) \\
6.5\end{array}$ & $\begin{array}{l}\text { (1) } \\
17.7\end{array}$ \\
\hline South Western & $\begin{array}{c}(58 / 899) \\
5.3\end{array}$ & $\begin{array}{c}(126 / 713) \\
18 \cdot 3\end{array}$ \\
\hline Midlands & $\begin{array}{c}(47 / 880) \\
5.3\end{array}$ & $\left.\begin{array}{c}(131 / 717) \\
16 \cdot 1\end{array}\right)$ \\
\hline Wales & $\begin{array}{c}(75 / 1424) \\
5.5 \\
(42 / 761)\end{array}$ & $\begin{array}{c}(182 / 1130) \\
16 \cdot 3 \\
(106 / 651)\end{array}$ \\
\hline Total & $\begin{array}{c}5 \cdot 0 \\
(735 / 14495)\end{array}$ & $\begin{array}{c}16 \cdot 6 \\
(1888 / 11406)\end{array}$ \\
\hline
\end{tabular}

fairly consistent, with low prevalence in the northerly regions, including Scotland, intermediate prevalence in the west of England and Wales, and high prevalence in the south and east of England. A formal comparison of the two regional distributions, as described in the methods section, suggested that both could reasonably be chance variations from a common geographical pattern $\left(\chi^{2}=11 \cdot 8, \mathrm{df}=11, \mathrm{p}=0.38\right)$.

The regional pattern of hay fever at 23 was based upon larger number of cases and was therefore used for comparison with the geographical distribution of childhood asthma. The distribution of hay fever differed significantly from that for both cumulative prevalence $\left(\chi^{2}=40.6, \mathrm{df}=11, \mathrm{p}<0.0001\right)$ and annual period prevalence $\left(\chi^{2}=46.0, \mathrm{df}=11\right.$, $\mathrm{p}=<0.0001)$ of asthma or wheezy bronchitis at age 7 in the same cohort.

INTERREGIONAL MIGRATION IN EACH COHORT

The prevalence of wheezing illness among migrants and non-migrants at age 5 (1970 cohort) or 7 ( 1958 cohort) is shown in table V. Overall, the prevalence of wheezing illness in the past year was

Table $V$ Prevalence of childhood asthma or wheeze among interregional migrants and non-migrants in the 1958 and 1970 cohorts. Numbers of children in parentheses

\begin{tabular}{|c|c|c|}
\hline & $\begin{array}{l}1958 \text { cohort: } \\
\% \text { with asthmal } \\
\text { wheezy bronchitis } \\
\text { in past year } \\
\text { at age } 7 \text { years }\end{array}$ & $\begin{array}{l}1970 \text { cohort: } \\
\text { o o with wheezing } \\
\text { in past year } \\
\text { at age } 5 \text { years }\end{array}$ \\
\hline $\begin{array}{l}\text { Region age } 7(5) \text { years } \\
\text { lower risk than } \\
\text { region of birth }\end{array}$ & $\begin{array}{c}7 \cdot 7 \\
(59 / 764)\end{array}$ & $\begin{array}{c}8 \cdot 2 \\
(47 / 571)\end{array}$ \\
\hline Non-migrants & $\begin{array}{c}9 \cdot 1 \\
(1036 / 11354)\end{array}$ & $\begin{array}{c}9.9 \\
(1054 / 10685)\end{array}$ \\
\hline $\begin{array}{l}\text { Region at } 7(5) \\
\text { years higher risk } \\
\text { than region of birth }\end{array}$ & $\begin{array}{c}10 \cdot 0 \\
(74 / 738)\end{array}$ & $\begin{array}{c}11.7 \\
(86 / 732)\end{array}$ \\
\hline Total & $\begin{array}{c}9 \cdot 1 \\
(1169 / 12856)\end{array}$ & $\begin{array}{c}9.9 \\
(1187 / 11988)\end{array}$ \\
\hline
\end{tabular}


similar for migrants and non-migrants $(8.8 \% v$ $9.1 \%$ in the 1958 cohort, $10.2 \% v 9.9 \%$ in the 1970 cohort). However, when the migrants were subdivided according to their direction of migration, using the prevalence among nonmigrants to rank regions, in each cohort those moving to a region of higher risk had a higher prevalence of wheezing than those moving to a region of lower risk.

This simple analysis by direction of migration is potentially misleading, because it does not take into account the magnitude of the difference between the risk in the region of birth and the region of current residence, and because subjects who move to a region of higher risk will tend to have been born in regions of low risk (and vice versa). Multiple logistic regression models, as described in the methods section, were fitted for each cohort to resolve these issues.

In a model for the 1958 cohort with asthma and/or wheezy bronchitis in the past year at age 7 as the outcome variable, the variation by region of birth, independent of region of residence at 7 , was negligible $\left(\chi^{2}=0 \cdot 12, \mathrm{df}=1\right)$. The trend towards higher prevalence among those living in high risk regions at 7 , independent of region at birth, was significant $\left(\chi^{2}=6.06, \mathrm{df}=1, \mathrm{p}=0.014\right)$. There was no substantial difference between migrants and non-migrants, after adjustment for regions of birth and current residence $\left(\chi^{2}=0 \cdot 22, \mathrm{df}=1\right)$.

An equivalent analysis in the 1970 cohort, using wheezing in the past year at age 5 as the outcome, again showed little variation by region of birth, after adjustment for region at $5\left(\chi^{2}=0.60, \mathrm{df}=1\right)$. However, the trend towards higher prevalence of wheeze among children living in a high risk region at 5, adjusted for region of birth, was highly significant $\left(\chi^{2}=9 \cdot 24, \mathrm{df}=1, \mathrm{p}=0.002\right)$. Again, the difference between migrants and nonmigrants was negligible $\left(\chi^{2}=0 \cdot 09, \mathrm{df}=1\right)$.

\section{Discussion}

Previous studies have described the regional variation in childhood asthma in the 1958 cohort and pointed to the low prevalence in Scotland and the high prevalence in Wales. ${ }^{14} 15$ We prefer to combine asthma and wheezy bronchitis for analysis because there is clinical ${ }^{16}$ and epidemiological ${ }^{17}$ evidence to suggest that they are part of a single disease category, with a spectrum of severity. This minimises problems of regional and social differentials in disease labelling, and allows a more direct comparison with the information from the 1970 cohort, which includes reports of symptoms, as well as diagnoses. Although they are based upon different age groups and questionnaire items, the similarity of the prevalence figures for wheeze in the past year, and for multiple attacks in the past year in the two cohorts is remarkable, particularly against the background of increasing rates of mortality and hospital admission for asthma ${ }^{18}$ and the rise in prevalence of eczema in early childhood reported in successive birth cohorts since the Second World War. ${ }^{19}$

Within each cohort, the regional variation in wheezing illness in primary school children was greater than would be expected by chance, but there were also differences between the geographical patterns in each cohort which, although not statistically significant at the conventional $5 \%$ level, were rather greater than might be expected from sampling variation. One possible explanation is that awareness of asthma and wheeze varied by region, and in a different manner in each cohort. If this were so, one might expect an excessive reporting of milder cases of wheeze in the higher prevalence regions. Using one criterion of severity (frequency of attacks in the past year), there did not seem to be overreporting of mild cases, except, perhaps, in the Midland region in the 1958 cohort. On the other hand, the regional differentials had largely disappeared by age 11 in the 1958 cohort, so cases with a better prognosis seem to account for much of the variation seen at age 7 .

The one constant feature was the low prevalence of wheeze in Scotland. Although Scottish children were also at low risk of other atopic conditions, the overall geographical pattern of hay fever and eczema was different from that for wheezing in childhood. Furthermore, if the low prevalence of wheeze in Scotland were to be attributed to a low prevalence of the inherited predisposition to atopy, it might be expected that region of birth would be more important than region of current residence as a determinant of the prevalence of wheeze.

The migrant analyses demonstrated clearly that the regional differentials in each cohort arose primarily as a result of factors associated with the child's region of current residence. This would be incompatible with suggestions that the geography of asthma is determined solely by genetic predisposition or by experiences early in childhood. Regional differences in reporting behaviour or family lifestyle could explain the effect of current residence only if they were acquired by parents moving to a new region. It is more likely that parents will be influenced to a greater extent by attitudes derived from their own upbringing, which they would carry with them when they move. Nevertheless, field studies of objective measures of disease, such as bronchial reactivity, ${ }^{1620}$ are required to evaluate the role of symptom reporting rigorously. Scotland deserves special attention because its low prevalence is consistent in both cohorts.

If regional variations in reporting behaviour or family lifestyle do not account for the differentials that we have described, then the implication of the migrant analyses is that environmental exposures vary sufficiently within a developed country such as Britain to cause measurable geographic variation in the prevalence of wheezing in childhood. The rather poor correlation between prevalence figures for the English regions in the two cohorts may be a useful clue to the nature of the relevant exposure. Viral respiratory infections are the commonest trigger of wheezing episodes in children, ${ }^{21}$ even among atopic subjects. ${ }^{22}$ It is possible that epidemics of viral infection affecting each cohort were, by chance, distributed differently between regions during the year before case ascertainment.

The lack of regional variation at older ages may be as important as the presence of differentials in young children. This may reflect the greater importance of non-infectious triggers of wheeze 
in adolescence. If the major determinants of asthma in British teenagers are distributed evenly with respect to both region and social background, ${ }^{6}$ then aetiological enquiry may need to be focused on a different level of causation. ${ }^{23}$ The continuing follow up of the 1970 cohort $^{24}$ should help to clarify the social and geographical epidemiology of wheezing illness in adolescence and early adult life.

We wish to thank the NCDS User Support Group and the ESRC Data Archive for assistance in accessing the National Child Development Study database, and Mr T Shenton for preparing a subset of the Child Health and Education Study database.

1 Waite DA, Eyles EF, Tonkin SL, O'Donnell TV. Asthm prevalence in Tokelauan children in two environments. Clin Allergy 1980; 10: 71-5.

2 Van Niekerk CH, Weinberg EG, Shore SC, Heese H de V, Van Schalkwyk DJ. Prevalence of asthma: a comparative study of urban and rural Xhosa children. Clin Allergy 1979, 9: 319-24.

3 Gregg I. Epidemiological research in asthma: the need for broad perspective. Clin Allergy 1986; 16: 17-23.

4 Smith JM, Harding LK, Cumming G. The changing prevalence of asthma in schoolchildren. Clin Allergy 1971; 1: 57-61.

5 Partridge MR, Gibson GJ, Pride NB. Asthma in Asian immigrants. Clin Allergy 1979; 9: 489-94.

6 Anderson HR, Bland JM, Patel S, Peckham C. The natural history of asthma in childhood. $f$ Epidemiol Community Health 1986; 40: 121-9.

7 Butler NR, Golding J. From Birth to Five. A study of the health and behaviour of Britain's 5-year-olds. Oxford: Pergamon Press, 1986.
8 Butler NR, Bonham DG. Perinatal mortality. First report of the 1958 British perinatal mortality survey, under the auspices of the National Birthday Trust Fund. Edinburgh Livingstone, 1963.

9 Shepherd PM. The National Child Development Study: an introduction to the origins of the study and the methods of dat collection. Lond NCDS User Support Group, City University, 1985.

10 Chamberlain R, Chamberlain G, Howlett B, Claireaux A British Births 1970. Vol 1. The first week of life. London: British Births 1970. Vol 1. The first week of life. London:

11 General Register

1 General Register Office. Census England and Wales 1951 General Report. London: HMSO, 1954.

12 SAS Institute Inc. $S A S$ user's guide: basics, version 5 edition and Statistics, version 5 edition. Cary, NC: SAS Institute, 1985.

13 Baker RJ, Nelder JA. The GLIM system manual. Release 3. Oxford: Numerical Algorithms Group, 1978.

14 Davie R, Butler N, Goldstein H. From Birth to Seven. The second report of the National Child Development Study 1958 cohort). London: Longman, 1972.

15 Kaplan BA, Mascie-Taylor CGN. Biosocial factors in the epidemiology of childhood asthma in a British national sample. F Epidemiol Community Health 1985; 39: 152-6.

16 Lee DA, Winslow NR, Speight ANP, Hey EN. Prevalence and spectrum of asthma in childhood. $B r$ Med $\mathcal{F} 1983 ; 286$ : and spe-8.

17 Williams HE, McNichol KN. Prevalence, natural history and relationship of wheezy bronchitis to asthma in children An epidemiological study. $\mathrm{Br}$ Med $\mathcal{f} 1969 ; 4: 321-5$.

18 Burr ML. Is asthma increasing? $f$ Epidemiol Community Health 1987; 41: 185-9.

19 Taylor B, Wadsworth J, Wadsworth M, Peckham C Changes in the reported prevalence of childhood eczema since the 1939-45 war. Lancet 1984; ii: 1255-7.

20 Strachan DP. Damp housing and childhood asthma validation of reporting of symptoms. Br Med F 1988; 297: 1223-6.

21 Horn MEC, Reed SE, Taylor P. Role of viruses and bacteria in acute wheezy bronchitis in childhood: a study of sputum. Arch Dis Child 1979; 54: 587-92.

22 Carlsen KH, Orstank I, Leegaard J, Hoeg H. Respiratory virus infections and aeroallergens in acute bronchial virus infections and

23 Anderson HR. Respiratory illness in childhood. Br Med Bull 1986; 42: 167-71.

24 Park ES, Golding J, Carswell F, Stewart-Brown S. Preschool wheezing and prognosis at 10. Arch Dis Child 1986; 61: $642-6$. 